\title{
Differential diagnosis of respiratory viral infections in children during the COVID-19 pandemic
}

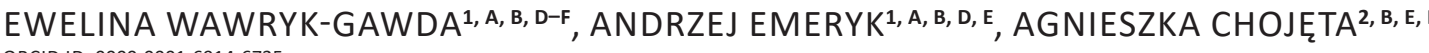 \\ ORCID ID: 0000-0001-6914-6735 \\ ${ }^{1}$ Department of Paediatric Pulmonology and Rheumatology, Medical University of Lublin, Lublin, Poland \\ ${ }^{2}$ Medical Laboratory DIAGNOSTYKA, Lublin, Poland
}

A - Study Design, B - Data Collection, C - Statistical Analysis, D - Data Interpretation, E - Manuscript Preparation, F - Literature Search, G - Funds Collection

Summary Background. Respiratory tract infections (RTIs) constitute the most common reason for pediatric patients to report to primary care facilities. Additionally, RTIs are also a significant problem among hospitalized patients. Due to the lack of specificity in the observed symptoms, RTIs cause both diagnostic and therapeutic difficulties.

Objectives. The aim of our study was to explain the causes of RTIs in the pediatric population and to provide guidelines to facilitate diagnosis.

Material and methods. In the study, the authors analyzed available literature dealing with the possibility of laboratory diagnosis and the results of treatment used in children with RTIs.

Results. In pediatric patients, RTIs are mainly caused by viruses and occur seasonally during the autumn-winter period. There are certain factors, such as physiological distinctness resulting from developmental immaturity of the body, genetically determined diseases and specific diseases occurring during childhood, which contribute to the incidence of RTIs. Moreover, factors depending on the mother and the growth environment also significantly affect the incidence of RTIs in children.

Conclusions. Available knowledge concerning the seasonality of the occurrence of individual pathogens and the differences in symptoms may facilitate an initial diagnosis. However, lower respiratory tract infections, and severe infections in particular, require the use of specific diagnostic tests which allow for both the identification of the etiological factors and the implementation of targeted treatment. The COVID-19 pandemic has highlighted the difficulties in the diagnosis and therapy of RTIs in pediatric patients, as well as the need to develop more sensitive diagnostic tools and a more effective treatment.

Key words: infections, respiratory tract diseases, viruses, SARS-CoV-2, COVID-19, human influenza, rhinovirus, hypersensitivity.

Wawryk-Gawda E, Emeryk A, Chojęta A. Differential diagnosis of respiratory viral infections in children during the COVID-19 pandemic. Fam Med Prim Care Rev 2021; 23(4): 501-507, doi: https://doi.org/10.5114/fmpcr.2021.110372.

Respiratory tract infections (RTIs) constitute both the most common reasons (about 70\%) for reporting to a primary care physician and a frequent cause (about 20\%) for hospitalization of children and adults $[1,2]$. The frequency of the appearance of RTIs varies depending on the age of the patient and concomitant risk factors.

The most important symptoms of RTIs include: runny nose, sore throat, cough, fever, lack of appetite or weakness [3]. Due to the lack of specificity in the observed symptoms, the identification of the main cause of the appearance of RTIs is difficult. Some of the pathogens responsible for the appearance of RTIs are epidemiologically seasonal or/and provide a common clinical picture facilitating diagnosis [3]. The choice of an appropriate therapeutic procedure should be preceded by the best possible diagnosis, in particular in the case of severe infections [1, 4-6].

The aim of the publication was to develop a diagnostic guideline for viral respiratory infections in children. The authors analyzed available literature dealing with the possibility of a laboratory diagnosis and the results of treatment used in children with RTIs. The authors' intention was to develop a set of clear and simple guidelines aiding practicing doctors in the process of making a diagnosis and choices for treatment. In our work, we analyzed typical causes and features of clinical symptoms of diseases in children in clear and understandable tables. We also showed available tests that should be used to improve the diagnosis of viral diseases in the pediatric population.

\section{Viral respiratory infections in children}

RTIs in children are most often caused by viruses, accounting for $85-90 \%$ of all respiratory infections $[5,7]$. In the Northern Hemisphere, depending on the age, the socio-economic status of the patient and the time of year, as well as different viruses, may be responsible for the appearance of RTIs (Table 1). Data collected in different regions of the world (Australia, South-East Asia, South America) show that in children aged 6 months to 10 years and treated as an outpatient for RTIs, the following constitute the most common reason for RTIs: human rhinoviruses (hRV) $-41.5 \%$, influenza viruses (IV) $-15.8 \%$, human adenoviruses (hAdV) - 9.8\%, human parainfluenza viruses (hPIV) and respiratory syncytial virus (RSV) - both $9.7 \%$, human coronaviruses (hCoV) $-5.6 \%$, human metapneumovirus (hMPV) $-5.5 \%$ and human bocavirus (hBoV) $-2.0 \%$ [8]. On the other hand, a study conducted on outpatient pediatric patients in Italy indicated the following: RSV $-27.1 \%, \mathrm{hAdV}-23.6 \%$, hCoV $-15.3 \%$, IV $-11.5 \%$, hBoV $-9.4 \%$, hPIV $-6.6 \%$, hMPV $-4.4 \%$ and human enteroviruses (hEV) $-2.1 \%$ [9]. The most commonly appearing viruses causing RTIs in hospitalized children (there are large differences between individual studies) are the following: RSV, hAdV, hRV, IV, PIV type 1, 2, 3, hCoV, hMPV and hBoV [10-12]. The incubation time for infections caused by individual viruses ranges from 1 to 15 days, and so far, only two vaccines against two viruses and three specific antiviral drugs are available (Table 1). 


\begin{tabular}{|c|c|c|c|c|}
\hline Viruses & Time of year* & Incubation (days) & Vaccines & $\begin{array}{l}\text { Specific antiviral } \\
\text { drugs }\end{array}$ \\
\hline Human rhinoviruses (hRV) & March-October & $1-2$ & - & - \\
\hline $\begin{array}{l}\text { Coronaviruses (SARS-CoV-1, MERS-CoV, } \\
\text { SARS-CoV-2) }\end{array}$ & $\begin{array}{l}\text { October-June } \\
\text { (whole year) }\end{array}$ & $2-5$ & $\begin{array}{l}+ \\
\text { (SARS-CoV-2) }\end{array}$ & during trials \\
\hline Influenza viruses (IV) & November-March & $1-4(6)$ & + & + \\
\hline Human parainfluenza viruses (hPIV) & autumn & $2-6$ & - & - \\
\hline Human adenoviruses (hAdV) & whole year & $4-5$ & - & - \\
\hline Human metapneumovirus (hMPV) & winter-spring & $2-3$ & - & - \\
\hline Coxsackieviruses & summer-autumn & $3-5$ & - & - \\
\hline Human bocavirus (hBoV) & winter-spring & ? & - & - \\
\hline Respiratory syncytial virus & November-April & $2-8$ & - & during trials \\
\hline Human herpesvirus 6 (hHSV-6) & spring-autumn & $5-15$ & - & + \\
\hline
\end{tabular}

* Northern Hemisphere temperate zone.

\begin{tabular}{|c|c|c|c|}
\hline Child-related factors & Maternal factors & Environmental factors & Medical care-related factors \\
\hline $\begin{array}{l}\text { Low birth weight and prema- } \\
\text { turity }\end{array}$ & short period of breastfeeding & $\begin{array}{l}\text { low socio-economic status, poor } \\
\text { housing conditions, contact with } \\
\text { moisture }\end{array}$ & abuse of antibiotic therapy \\
\hline $\begin{array}{l}\text { Genetic diseases (cystic fibrosis, } \\
\text { ciliary mobility disorders, defi- } \\
\text { ciency of } \alpha 1 \text {-antitrypsin) }\end{array}$ & $\begin{array}{l}\text { the use of stimulants, e.g. } \\
\text { tobacco, alcohol }\end{array}$ & $\begin{array}{l}\text { exposure to tobacco smoke and } \\
\text { air pollution }\end{array}$ & lack of preventive vaccinations \\
\hline $\begin{array}{l}\text { Anatomical differences, a small } \\
\text { distance between the nasal } \\
\text { and oral cavities and the lower } \\
\text { respiratory tract }\end{array}$ & $\begin{array}{l}\text { lack of proper diet, malnutrition } \\
\text { during pregnancy and lactation }\end{array}$ & having an older sibling & $\begin{array}{l}\text { insufficient prevention of infec- } \\
\text { tions }\end{array}$ \\
\hline $\begin{array}{l}\text { Limited possibilities of expec- } \\
\text { toration }\end{array}$ & & $\begin{array}{l}\text { staying in large groups without } \\
\text { the possibility of isolation (nurs- } \\
\text { ery, kindergarten, school) }\end{array}$ & \\
\hline \multicolumn{4}{|l|}{ Immature immune system } \\
\hline \multicolumn{4}{|l|}{$\begin{array}{l}\text { Predisposition to foreign body } \\
\text { aspiration to the respiratory } \\
\text { tract }\end{array}$} \\
\hline \multicolumn{4}{|l|}{ Gastroesophageal reflux } \\
\hline Food and respiratory allergy & & & \\
\hline
\end{tabular}

In the Northern Hemisphere, the intensification of the incidence of RTIs, and upper respiratory tract infections (URTIS) in particular, is usually observed seasonally in the autumn-winter and early-spring periods $[4,5]$. RTIs caused by hEV and hCoV do not show marked seasonality, and rhinoviral etiology is dominant in late summer $[2,13]$. Moreover, there is a possibility of the appearance of simultaneous co-infections caused by various viruses, as well as the existence of the carrier of various viruses, especially in the case of the upper respiratory tract $[5,13,14]$. Due to the possibility of its severe clinical course and high infectivity, the SARS-CoV-2 (Severe Acute Respiratory Syndrome Coronavirus 2) pandemic requires that COVID-19 (Coronavirus Disease 2019) patients should be separated from patients with viral infections of a different etiology.

\section{Factors contributing to respiratory tract infections in children}

RTIs are more common in children than in adults for numerous reasons (Table 2). Knowledge of these reasons allows one to determine indications for a possible extension of diagnosis and to refer these patients to a specialist pulmonologist or clinical immunologist in the case of the appearance of atypical and disturbing symptoms which are unusual for the developmental age [15-20].

\section{Epidemiological and clinical characteristics of selected viral RTIs in children}

\section{Influenza}

Influenza is caused by viruses belonging to the Orthomyxoviridae family. Based on the differences in the organization of the genome, several types of influenza viruses (IV) have been identified. The most widespread human influenza virus is the influenza A virus, which is epidemic. Influenza is less frequently caused by the influenza $B$ virus, while the type $C$ virus is responsible for respiratory infections with a mild course [21]. Most influenza cases occur seasonally from autumn to spring, and the incubation period of the disease is 2 to 4 days (Table 1). Flu symptoms appear suddenly and include: high fever above $38^{\circ} \mathrm{C}$, chills, muscle ache and headache, malaise, non-productive cough, less frequently chest pain and abdominal pain, nausea and vomiting [22-26]. Symptoms usually appear simultaneously in the first days of the illness, and in many cases, they are self-limiting within a week. However, the occurrence of complications during the course of the disease and after are more and more commonly observed, and they include pneumonia, bronchitis, middle ear inflammation, myositis, meningitis and even death [27]. It should be remembered that infection caused by the influenza virus and other viruses may exacerbate the course 
of chronic diseases such as asthma $[28,29]$. In addition, influenza takes the form of an annual epidemic and causes infections in many people, resulting both in numerous school absences in the case of pediatric patients and sick leaves in adults. Therefore, the role of the use of oseltamivir in the treatment of patients with influenza, as well as in the prevention of diseases in people exposed to contact, has been emphasized for several years. There are a few types of vaccines available as well [30].

\section{RSV infections}

The respiratory syncytial virus (RSV) belongs to the Paramyxoviridae family and is responsible for human respiratory tract infections all over the world. In adults and older children, RSV infection is clinically associated with upper respiratory symptoms, while in infants, RSV causes bronchiolitis and lower respiratory tract illness that can progresses to pneumonia [31].

Coughing and wheezing are common with RSV and rhinovirus type $\mathrm{C}$ respiratory infections and can be difficult to distinguish from non-infectious (allergenic) asthma exacerbations, especially when the course of disease is without a fever. However, the age of the patient is an important feature that differentiates these disease: RSV infections with obstruction of the lower respiratory tract (bronchiolitis) are more common in younger children (mainly between the age of 6 weeks and 6 months), while allergic asthma exacerbations are usually observed in preschool and school children (Table 3).

RSV infections and the exacerbations of asthma (caused by intense contact with the allergen the child is allergic to) may occur simultaneously. Interestingly, there is even data indicating that the first episode of asthma may be related to an RSV infection. In such cases, bearing in mind that RSV (and RV) infections may develop into pneumonia, respiratory disorders, apnea and, in rare cases, can lead to death, the testing for RSV infection is the decisive diagnostic element and enables the implementation of appropriate treatment $[2,13,18,31-33]$. In the case of an infection caused by several viruses, no more severe course of the disease should be expected, since the co-infection with RSV, hRV and IV usually leads to a reduction in growth of the second virus $[2,34,35]$.

\section{hMPV infections}

hMPV causes about $7 \%$ of RTIs in children, both hospitalized and treated as an outpatient, aged 1-5 [36]. As with RSV and influenza viruses, it occurs seasonally, in late winter and spring [37]. In premature babies and children with reduced immunity, the infection is severe and requires hospitalization. The peak age of hospitalization of infants with hMPV is $6-12$ months, and the clinical course of the infection is similar to that of RSV infection [38].

\section{hBoV infections}

It is estimated that in terms of the number of cases and after RSV and hMPV, hBoV is the third pathogen causing RTIs in children 5 years of age or less (mainly those between 3 months and 3 years of age) [39]. The incidence of hBoV types 1-4 in children is $10-30 \%$ [40]. Although the majority of hBoV cases occur in the winter months, it is common throughout the year. The symptoms are non-specific, but the most common symptoms in the course of the disease are the following: cough, runny nose, fever, difficulties in breathing, conjunctivitis, erythema, rash, nausea and sore throat [41].

\section{SARS-CoV-2 infections}

Since 2019, the differential diagnosis of RTIs should take into account infections caused by SARS-CoV-2. In the pediatric COVID-19 population, the disease caused by coronavirus usually presents as mild upper respiratory tract infections (URTIs) and/or lower respiratory tract infections (LRTIS) with a cough, rhinitis, sore throat and mild fever [42-44]. Less frequent are vomiting, diarrhea, loss of smell and taste and cardiovascular symptoms (chest pain, myocarditis, arrhythmia) [45-47]. It is uncommon for the symptoms to appear simultaneously, and they usually appear over the course of the disease on consecutive days. After the patient's condition has improved for several days, another deterioration can be expected. Coughing and weakness may persist for several weeks after recovery from the illness. A few cases of children developing multiple organ failure, acute respiratory distress syndrome (ARDS) and isolated cases of death in the course of COVID-19 have been reported [42-48].

Table 3 shows the frequency of COVID-19 symptoms in children based on available publications. Less severe symptoms in the pediatric population, as well as more frequent asymptomatic SARS-CoV-2 infections when compared to the adult population, are probably associated with a lower expression of ACE2 receptors (Angiotensin Converting Enzyme 2) in the epithelium of the oral cavity, nasal passages and lower respiratory tract, as well as a higher concentration of ACE2 in the blood, which further reduces the possibility of the virus binding to ACE2 receptors [47]. Factors that increase the risk of a severe course of COVID-19 in children include an age below 30 days, male gender, chronic diseases of the nervous, cardiac, respiratory and urinary systems, immunosuppression, obesity and co-infection with the influenza virus or RSV [27].

\begin{tabular}{|l|l|l|l|l|l|l|}
\hline Table 3. Symptoms of viral RTls and allergic rhinitis in children [48-52, with our modification] \\
\hline Clinical feature & COVID-19 & Influenza & $\begin{array}{l}\text { Viral * rhinitis and } \\
\text { pharyngitis }\end{array}$ & RSV infection & $\begin{array}{l}\text { Allergic rhinitis } \\
\text { (exacerbation) }\end{array}$ \\
\hline Runny nose & rarely & often & often & sometimes & very often \\
\hline Nasal congestion & sometimes & sometimes & often & often & often \\
\hline Sneezing & rarely & sometimes & often & rarely & often, in peals $\geq 3$ \\
\hline Loss of smell & sometimes (children & sometimes & sometimes & rarely & sometimes \\
\hline Nasal itching & rarely & sometimes & rarely & rarely & very often \\
\hline $\begin{array}{l}\text { Conjunctivitis } \\
\text { Sometimes }\end{array}$ & sometimes & rarely & rarely & $\begin{array}{l}\text { often (seasonal } \\
\text { rhinitis) }\end{array}$ \\
\hline $\begin{array}{l}\text { Shortness of breath } \\
\text { (dyspnea) }\end{array}$ & sometimes & rarely & often & rarely & often & quite often \\
\hline $\begin{array}{l}\text { Additional ausculta- } \\
\text { tory phenomena }\end{array}$ & often & rarely & never & often & - \\
\hline
\end{tabular}




\begin{tabular}{|l|l|l|l|l|l|l|}
\hline \multicolumn{7}{|l|}{ Table 3. Symptoms of viral RTIs and allergic rhinitis in children [48-52, with our modification] } \\
\hline Clinical feature & COVID-19 & Influenza & $\begin{array}{l}\text { Viral * rhinitis and } \\
\text { pharyngitis }\end{array}$ & RSV infection & $\begin{array}{l}\text { Allergic rhinitis } \\
\text { (exacerbation) }\end{array}$ \\
\hline Fever & often $\left(<38^{\circ} \mathrm{C}\right)$ & often $\left(>38^{\circ} \mathrm{C}\right)$ & sometimes & sometimes & never \\
\hline Myalgia & sometimes & often & rarely & sometimes & never \\
\hline Malaise & often & sometimes & often & sometimes & sometimes \\
\hline Sore throat & sometimes & quite often & often & rarely & sometimes (mild) \\
\hline $\begin{array}{l}\text { Throat or palate } \\
\text { itching }\end{array}$ & never & never & never & rarely & sometimes \\
\hline Diarrhea & rarely & sometimes & rarely & rarely & - \\
\hline $\begin{array}{l}\text { Duration of symp- } \\
\text { toms }\end{array}$ & 7-16 days & 5-10 days & 3-14 days & 4-11 days & weeks, months \\
\hline Age & in each age & in each age & in each age & under 3 years & adolescent and adult \\
\hline Another & sudden onset & sudden onset & slowly onset & $\begin{array}{l}\text { bronchiolitis, } \\
\text { appetite decreased }\end{array}$ & $\begin{array}{l}\text { positive allergy inter- } \\
\text { view, slow, lengthy } \\
\text { process }\end{array}$ \\
\hline
\end{tabular}

* hRV and other viruses causing the common cold.

\section{Differential diagnosis of acute RTIs}

Acute infection of the nasal mucosa and paranasal sinuses, pharyngitis and tonsillitis, otitis, laryngitis and tracheitis belong to the URTI group - the group of the most common diseases in pediatrics (especially in children 1-6 years of age), although they are also of interest to an ENT specialist, an allergist or an immunologist $[2,34,53]$. In children, URTIs usually have an acute and short course, sometimes recurrent (> 2-6 episodes per year, depending on the age and the disease), usually without permanent consequences $[20,53]$.

If the patient presents a number of various upper respiratory symptoms, we are in fact faced with at least three questions:

1. Is it a URTI or an exacerbation of allergic rhinitis (AR)?

2. What kind (clinical form) of URTIs are we dealing with?

3. What is the etiological factor of the URTI?

A carefully collected medical history is helpful in the process of a differential diagnosis (Table 3, 4). For example, the following symptoms indicate an allergic background of symptoms in the form of AR occurring seasonally during the pollination of wind-pollinated plants to allergens to which the patient is allergic: sneezing in series, itching of the nose, itching and tearing of the conjunctiva or rhinorrhea [16, 24]. A physical examination of patients with AR will show congested conjunctivitis, shadows under the eyes, transverse nasal crease, pale blue staining and swelling of the nasal auricles in the anterior rhinoscopy [24, 54].

The occurrence of fever, mucopurulent secretion in the nasal canals, enlarged lymph nodes and a sudden onset of the disease will suggest an infectious etiology (Table 3 ). In contrast, viral tonsillitis is often accompanied by conjunctival, laryngeal, nasal and sinus symptoms, muscle and joint pains and abdominal pain with diarrhea. A physical examination will show typical bubbles on the mucous membrane of the soft palate and, in the history, a slow increase in symptoms. However, sudden onset, difficulty in swallowing, fibrous deposits or purulent secretion on the tonsils suggest bacterial etiology $[4,33,55]$. The differentiation of etiology in different clinical forms of URTIs in children has been collected in Table 4 .

The usefulness of CRP and/or procalcitonin determinations in the differential diagnosis of viral and bacterial URTIs in children is still questionable. In light of the latest meta-analyses, the determination of CRP or procalcitonin may be useful in primary health care or HEDs (hospital emergency departments) to make the right decision concerning antibiotic therapy in patients with acute forms of respiratory tract infections [56, 57]. However, the interpretation of these proteins seems to be increasingly subjective. Therefore, there have been attempts to obtain more objective markers of inflammation, such as proteins related to TNF (tumor necrosis factor) and interferon $\gamma$ [58].

\begin{tabular}{|c|c|c|c|}
\hline Disease & Viral ethology & $\begin{array}{l}\text { Bacterial } \\
\text { ethology }\end{array}$ & Tests \\
\hline $\begin{array}{l}\text { Acute pharyn- } \\
\text { gitis }\end{array}$ & $\begin{array}{l}\text { cough, runny } \\
\text { nose }\end{array}$ & $\begin{array}{l}\text { without cough } \\
\text { lymphade- } \\
\text { nopathy }\end{array}$ & $\begin{array}{l}\text { throat swab, } \\
\text { rapid strep } \\
\text { a antigen test }\end{array}$ \\
\hline $\begin{array}{l}\text { Acute otitis } \\
\text { media }\end{array}$ & $\begin{array}{l}\text { duration }<48 \\
\text { hours }\end{array}$ & $\begin{array}{l}\text { duration }>48 \\
\text { hours } \\
\text { in children }<1 \\
\text { year high fe- } \\
\text { ver, vomiting }\end{array}$ & $\begin{array}{l}\text { tests not } \\
\text { necessary }\end{array}$ \\
\hline $\begin{array}{l}\text { Acute rhinitis } \\
\text { and sinusitis }\end{array}$ & $\begin{array}{l}\text { duration }<7 \\
\text { days }\end{array}$ & $\begin{array}{l}\text { duration > } 10 \\
\text { days, } \\
\text { worsening in } \\
5-7 \text { days } \\
\text { pain and facial } \\
\text { swelling }\end{array}$ & $\begin{array}{l}\text { tests not } \\
\text { necessary }\end{array}$ \\
\hline
\end{tabular}

Infections of the lower respiratory tract (LRTI), especially of the bronchi and lungs, constitute a more likely cause of hospitalization than URTIs and may lead to permanent complications, such as impaired ventilation or the development of asthma [4, 49]. Among the etiological factors of LRTIs in children, viruses also predominate, and the course of the infection is often self-limiting. However, due to the recommended implementation of causal treatment in the case of bacterial diseases and influenza and the increased risk of permanent complications, causal diagnosis should be undertaken much more often than in the case of URTIs $[3,5,16,18]$. The best samples from the lower respiratory tract are obtained with the use of bronchoscopy, which is very infrequent in children. It is replaced with an easily accessible nasopharyngeal swab. Importantly, when interpreting the results, the possibility of carrying non-pathogenic viruses/bacteria should be considered [59].

Due to the difficulties or even inability to establish the etiology of RTIs based on a medical interview and physical examination, it is necessary to conduct additional tests, even in the primary health care facility. Over the last 20 years, great progress has been made in the diagnosis of viral RTIs, which is mainly related to the introduction and increase in use of methods based on the amplification of viral nucleic acids and antigen tests.

Diagnostic tests helpful in the differential diagnosis of viral RTIs are divided into 3 main groups [60]:

Antigenic (strip, cassette): immunofluorescent, enzyme immunoassay, e.g. ELISA and immunochromatographic tests - to detect the presence of virus antigens in the tested material. 
Genetic (molecular) - most often the RT-PCR method (reverse transcriptase polymerase chain reaction) - detecting the genetic material of the virus in the tested sample.

Serological: qualitative, semi-quantitative or quantitative assessment of the concentration of IgG and/or IgM in the blood.

The research materials include: nose or throat swab, bronchoalveolar lavage fluid, tracheal or bronchial aspirate. The advantages and disadvantages of diagnostic tests most often used in the diagnosis of viral RTs are presented in Table 5 [60].

The most popular tests aiding rapid identification of the pathogen are antigen tests, used as well as screening tests. The result is usually obtained within 10-30 minutes after the performance of the test. Such tests should be widely used by family doctors and pediatricians in primary care facilities and in emergency departments of hospitals. They differ in sensitivity and specificity. For example, in the case of rapid tests for detecting influenza A or B antigens, the sensitivity differs depending on the manufacturer from $53-54 \%$, with a specificity of $98 \%$. The sensitivity of the test usually decreases with the duration of the infection [61].

When IV, RSV or hAdV infections are suspected, a negative result should be confirmed by the method recognized as the golden standard, i.e. PCR (or RT-PCR). Particularly in the case of hospitalized patients, molecular tests identifying a given pathogen should be performed. Using the available tests, it is possible to obtain the results within 15-30 minutes from the start of the test, and their sensitivity is $95-99 \%$. The documented sensitivity tests should be used to minimize the possibility of a false result [62]. One study evaluated immunochromatic rapid antigen tests for COVID-19 - Ag Respi-Strip (Coris BioConcept, Gembloux, Belgium). However, their sensitivity turned out to be very low $30-50 \%$ compared to RT-PCR $[63,64)$. Currently, the so-called golden standard for testing for URTIs is a nasopharyngeal swab (Figure 1).

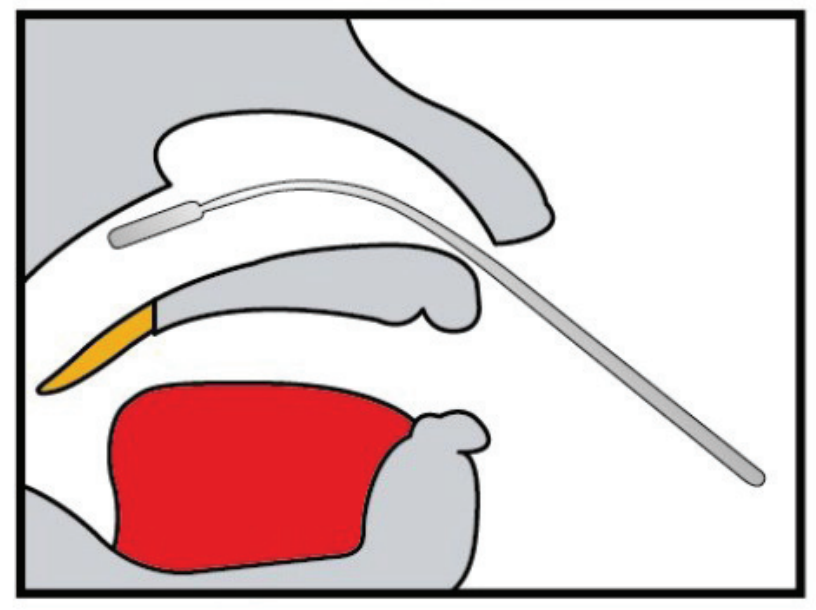

Figure 1. Taking a nasopharyngeal swab

Alternatively, a nasal swab and/or deep throat swab (positive opinion of the Polish National Institute of Hygiene for 2018 nose and throat swabs) can be taken. Importantly, the same swab brush should always be used to take the swab from both nostrils to increase the likelihood of detection of the RNA virus. The test result is also influenced by the time of sample delivery to the laboratory and the sample storage conditions. Moreover, performance of the test and interpretation of the result should be performed by the same person.

There are serological tests available on the market examining the level of IgA, IgM and IgG antibodies directed against
Table 5. Advantages and disadvantages of diagnostic tests most often used in the diagnosis of viral RTs

\begin{tabular}{|c|c|c|}
\hline Type of test & Advantages & Disadvantages \\
\hline Antigenic & $\begin{array}{l}\text { ease of execution } \\
\text { (Primary Health } \\
\text { Care, HED), screen- } \\
\text { ing test, simple } \\
\text { apparatus, short } \\
\text { execution time } \\
\text { - approx. 15-20 } \\
\text { minutes, cost of } \\
\text { a single test approx. } \\
\text { 10-15 times lower } \\
\text { than RT-PCR }\end{array}$ & $\begin{array}{l}\text { smaller sensitivity } \\
\text { vs RT-PCR }\end{array}$ \\
\hline $\begin{array}{l}\text { Genetic } \\
\text { RT-PCR }\end{array}$ & $\begin{array}{l}\text { the most sensitive } \\
\text { and specific test } \\
\text { (gold standard), } \\
\text { determination of } \\
\text { the number of } \\
\text { copies or units of } \\
\text { the virus in the } \\
\text { appropriate serum } \\
\text { volume, evaluation } \\
\text { of the virus variant } \\
\text { (mutations or char- } \\
\text { acteristic sequences } \\
\text { in the genome), the } \\
\text { presence of a small } \\
\text { virus titre (copies) is } \\
\text { sufficient }\end{array}$ & $\begin{array}{l}\text { requires experi- } \\
\text { enced personnel } \\
\text { and specialized } \\
\text { laboratory, high } \\
\text { cost, long testing } \\
\text { time (1-4 hours) }\end{array}$ \\
\hline Serological & $\begin{array}{l}\text { assessment of pop- } \\
\text { ulation immunity, } \\
\text { useful in epidemio- } \\
\text { logical studies and } \\
\text { confirmation of the } \\
\text { disease in a patient } \\
\text { without clinical } \\
\text { symptoms }\end{array}$ & $\begin{array}{l}\text { the need to col- } \\
\text { lect blood serum, } \\
\text { supplementary test }\end{array}$ \\
\hline
\end{tabular}

SARS-CoV-2. The WHO permits the application of these methods as a supplementary diagnosis method. The validity of blood serological tests is related to the fact that some patients experience a decrease in RT-PCR sensitivity after about a week after the onset of symptoms. The first antibodies may appear as early as 10 days after the onset of symptoms of the disease.

\section{Conclusions}

Infections of the respiratory tract in children are still an important diagnostic and therapeutic problem in primary health care, especially during the COVID-19 pandemic. The unspecific history and symptomatology of the majority of viral RTIs require diagnostic tests. The available knowledge concerning the seasonality of the occurrence of individual pathogens and the differences in the symptoms may facilitate initial diagnosis. However, lower respiratory tract infections, and severe ones in particular, require the use of specific diagnostic tests which allow for both the identification of the etiological factors and the implementation of targeted treatment. There is an urgent need to introduce rapid antigen tests to help determine the etiology of RTIs (especially LRTIs) in children, mainly for influenza, RSV, $\mathrm{RV}$ and SARS-CoV-2. Due to the COVID-19 pandemic, rapid progress in virological diagnostics and vaccinology should be expected, along with the availability of new antiviral drugs. 


\section{References}

1. Tregoning JS, Schwarze J. Respiratory viral infections in infants: causes, clinical symptoms, virology, and immunology. Clin Microbiol Rev 2010; 23(1): 74-98, doi: 10.1128/CMR.00032-09.

2. Annamalay A, Le Souëf P. Viral-bacterial interactions in childhood respiratory tract infections. Viral Infections in Children 2017; 1 : 193-214, doi: 10.1007/978-3-319-54033-7_8.

3. Nelson PP, Papadopoulos NG, Skevaki C. Respiratory viral pathogens. Reference Module in Biomedical Sciences 2020; B978-0-12801238-3.11635-6, doi: 10.1016/B978-0-12-801238-3.11635-6.

4. Zieliński R, Zakrzewska A. Ostre infekcje górnych dróg oddechowych u dzieci-podział morfologiczny, diagnostyka i terapia. Forum Med Rodz 2010; 4(5): 366-371 (in Polish).

5. Charlton $\mathrm{CL}$, Babady E, Ginocchio CC, et al. Practical guidance for clinical microbiology laboratories: viruses causing acute respiratory tract infections. Clin Microbiol Rev 2019; 32(1): e00042-e00018.

6. Kuchar E, Miśkiewicz K, Nitsch-Osuch A, et al. Pathophysiology of clinical symptoms in acute viral respiratory tract infections. Pulmonary Infection 2015; 857: 25-38.

7. Mazurek H, Mazurek-Durlak Z. Zakażenia układu oddechowego. Zagadnienia ogólne. In: Mazurek H, ed. Zakażenia układu oddechowego u dzieci. Warszawa: Medical Tribune Polska; 2014: 9-62 (in Polish).

8. Taylor S, Lopez P, Weckx L, et al. Respiratory viruses and influenza-like illness: epidemiology and outcomes in children aged 6 months to 10 years in a multi-country population sample. J Infect 2017; 74(1): 29-41.

9. Conto F De, Conversano F, Medici MC, et al. Epidemiology of human respiratory viruses in children with acute respiratory tract infection in a 3-year hospital-based survey in Northern Italy. Diagn Microbiol Infect Dis 2019; 94(3): 260-267.

10. Ambrosioni J, Bridevaux PO, Wagner G, et al. Epidemiology of viral respiratory infections in a tertiary care centre in the era of molecular diagnosis, Geneva, Switzerland, 2011-2012. Clin Microbiol Infect 2014; 20(9): 578-584, doi: 10.1111/1469-0691.12525.

11. Bonzel L, Tenenbaum $\mathrm{T}$, Schroten $\mathrm{H}$, et al. Frequent detection of viral coinfection in children hospitalized with acute respiratory tract infection using a real-time polymerase chain reaction. Pediatr Infect Dis J 2008; 27: 589-594.

12. Calvo C, Aguado I, García-García ML, et al. Grupo de Estudio de Sibilancias Recurrentes. Infecciones virales respiratorias en una cohorte de niños durante el primer año de vida y su papel en el desarrollo de sibilancias. An Pediatr (Barc) 2017; 87(2): 104-110, doi: 10.1016/j. anpedi.2016.08.002 (in Spanish).

13. Morikawa S, Kohdera U, Hosaka T, et al. Seasonal variations of respiratory viruses and etiology of human rhinovirus infection in children. J Clin Virol 2015; 73: 14-19, doi: 10.1016/j.jcv.2015.10.001.

14. Prasad S, Lownik E, Ricco J. Viral infections of the respiratory tract. Fam Med 2016; 17: 507-517.

15. Jesenak M, Ciljakova M, Rennerova Z, et al. Recurrent respiratory infections in children - definition, diagnostic approach, treatment and prevention. In: Martãn-Loeches I, ed. Bronchitis. Rijeka: InTech; 2011: 119-148.

16. Jung A. Zależności pomiędzy alergią a infekcjami układu oddechowego u dzieci - możliwości profilaktyki i terapii. Pediatr Med Rodz 2009; 5(3): 204-210 (in Polish).

17. Szczawińska-Popłonyk A, Samara H, Bręborowicz A, et al. The importance of studying B-cell surface markers in children with defective biosynthesis of antibodies. Alerg Astma Immunol 2012; 17(2): 97-102.

18. Vissing NH, Chawes BL, Rasmussen MA, et al. Epidemiology and risk factors of infection in early childhood. Pediatrics 2018; 141(6): e20170933, doi: 10.1542/peds.2017-0933.

19. Frank NM, Lynch KF, Uusitalo U, et al. The relationship between breastfeeding and reported respiratory and gastrointestinal infection rates in young children. BMC Pediatr 2019; 19(1): 339, doi: 10.1186/s12887-019-1693-2.

20. Barrett B. Viral upper respiratory infection. Integrative Medicine 2018; 18: 170-179.

21. Markowska-Daniel I, Mickiewicz M, Witkowski L, et al. Charakterystyka nowego wirusa grypy typu D. Med Weter 2016; 72(9): 531-535 (in Polish).

22. Zakład Epidemiologii Chorób Zakaźnych i Nadzoru, Pracownia Monitorowania i Analizy Sytuacji Epidemiologicznej. Zachorowania i podejrzenia zachorowań na grypę w Polsce [cited 1.02.2021]. Available from URL: http://wwwold.pzh.gov.pl/oldpage/epimeld/grypa/ index.htm (in Polish).

23. Rządowe Centrum Bezpieczeństwa. Grypa w sezonie epidemicznym 2018-2019 w Polsce i Europie [cited 1.02.2021]. Available from URL: https://rcb.gov.pl/grypa-w-sezonie-epidemicznym-2018-2019-w-polsce-i-europie/ (in Polish).

24. Emeryk A, Emeryk-Maksymiuk J, Jędrzejewski A. Nawrotowe zakażenia dróg oddechowych czy alergiczny nieżyt nosa? Alergoprofil 2019; 15: 1-5 (in Polish).

25. Epperson S, Davis CT, Brammer L, et al. Update: Influenza Activity - United States and Worldwide, May 19-September 28, 2019, and Composition of the 2020 Southern Hemisphere Influenza Vaccine. MMWR Morb Mortal Wkly Rep 2019; 68(40): 880-884, doi: 10.15585/mmwr.mm6840a3.

26. Ghebrehewet S, MacPherson P, Ho A. Influenza. BMJ 2016; 355: i6258, doi: 10.1136/bmj.i6258.

27. Uyeki TM, Bernstein HH, Bradley JS, et al. Clinical Practice Guidelines by the Infectious Diseases Society of America: 2018 Update on Diagnosis, Treatment, Chemoprophylaxis, and Institutional Outbreak Management of Seasonal Influenza. Clin Infect Dis 2019; 68(6): e1-e47, doi: 10.1093/cid/ciy866.

28. Lee FEH, Treanor JJ. Viral Infections. Murray and Nadel's Textbook of Respiratory Medicine. 2016: 527-556, e15, doi: 10.1016/B9781-4557-3383-5.00032-4.

29. Guibas GV, Papadopoulos NG. Viral upper respiratory tract infections. Viral Infections in Children, II. 2017, 5: 1-25.

30. Guibas GV, Papadopoulos NG. Viral upper respiratory tract infections. In: Green R, ed. Viral infections in children. Vol. II. Cham: Springer; 2017, doi: 10.1007/978-3-319-54093-1_1.

31. Doniec Z, Mastalerz-Migas A, Jackowska T, et al. Recommendations for the treatment of INFLUENZA in children for primary care physicians - COMPAS INFLUENZA. Fam Med Prim Care Rev 2019; 21(2): 189-198, doi: 10.5114/fmpcr.2019.82984.

32. Schweitzer JW, Justice NA. Respiratory Syncytial Virus Infection (RSV) [Updated 2020 Jul 26]. In: StatPearls [Internet]. Treasure Island (FL): StatPearls Publishing; 2020.

33. Barr R, Green CA, Sande CJ, et al. Respiratory syncytial virus: diagnosis, prevention and management. Ther Adv Infect Dis 2019; 6: 2049936119865798 , doi: 10.1177/2049936119865798.

34. Prejsnar-Rusyn P, Hajkuś R, Leszczyńska K, et al. Alergie. Co nowego w objawowym leczeniu alergicznego zapalenia błony śluzowej nosa i spojówek oraz pokrzywki. Analiza Przypadków. Pediatria 2018; 2 (in Polish).

35. Yen CY, Wu WT, Chang CY, et al. Viral etiologies of acute respiratory tract infections among hospitalized children - a comparison between single and multiple viral infections. J Microbiol Immunol Infect 2019; 52(6): 902-910, doi: 10.1016/j.jmii.2019.08.013.

36. Szczawińska-Popłonyk A. The immune response to respiratory syncytial virus infection. Alerg Astma Immunol 2008; 13(4): $208-216$. 
37. Edwards KM, Zhu Y, Griffin MR et al. Burden of human metapneumovirus infection in young children. N Engl J Med 2013; 368(7): 633-643.

38. Heikkinen T, Österback R, Peltola V, et al. Human Metapneumovirus infections in children. Emerg Infect Dis 2008; 14(1): 101-106.

39. Wilkesmann A, Schildgen O, Eis-Hübinger AM, et al. Human Metapneumovirus in hospitalized children - a review. Klin Padiatr 2007; 219(2): 58-65.

40. Zhou $L$, Zheng $S$, Xiao $Q$, et al. Single detection of human bocavirus 1 with a high viral load in severe respiratory tract infections in previously healthy children. BMC Infect Dis 2014; 14: 424, doi: 10.1186/1471-2334-14-424.

41. Peltola V, Soderlund-Venermo M, Jartii T. Human Bocavirus infections. J Ped Inf Dis 2013; 32(2): 178-179.

42. Abramczuk E, Gordon M, Jahnz-Różyk K, et al. Ludzkie wirusy Boca - nowe parwowirusy wywołujące zakażenia u ludzi. Forum Zakażeń 2015; 6(1): 43-47 (in Polish).

43. Saleem H, Rahman J, Aslam N, et al. Coronavirus Disease 2019 (COVID-19) in children: vulnerable or spared? A systematic review. Cureus 2020; 12(5): e8207, doi: 10.7759/cureus.8207.

44. Ciuca IM. COVID-19 in children: an ample review. Risk Manag Healthc Policy 2020; 13: 661-669, doi: 10.2147/RMHP.S257180.

45. She J, Liu L, Liu W. COVID-19 epidemic: disease characteristics in children. J Med Virol 2020; 92(7): 747-754, doi: 10.1002/jmv.25807.

46. Ludvigsson JF. Systematic review of COVID-19 in children shows milder cases and a better prognosis than adults. Acta Paediatr 2020; 109(6): 1088-1095, doi: 10.1111/apa.15270.

47. Zimmermann P, Curtis N. Coronavirus infections in children including COVID-19: an overview of the epidemiology, clinical features, diagnosis, treatment and prevention options in children. Pediatr Infect Dis J 2020; 39(5): 355-368, doi: 10.1097/INF.0000000000002660.

48. Yamamoto L, Santos EH dos, Pinto LS, et al. SARS-CoV-2 infections with emphasis on pediatric patients: a narrative review. Rev Inst Med Trop Sao Paulo 2020; 62: e65, doi: 10.1590/S1678-9946202062065.

49. Samoliński B, Arcimowicz M, Buczyłko K, et al. Polskie Standardy Leczenia Nieżytów Nosa-PoSLeNN. Kraków: Medycyna Praktyczna; 2013.

50. Wishaupt JO, Ploeg T van der, Groot R de, et al. Single- and multiple viral respiratory infections in children: disease and management cannot be related to a specific pathogen. BMC Infect Dis 2017; 17(1): 62, doi: 10.1186/s12879-016-2118-6.

51. Walsh EE. Respiratory syncytial virus infection: an illness for all ages. Clin Chest Med 2017; 38(1): 29-36, doi: 10.1016/j.ccm.2016.11.010.

52. Troullos E, Baird L, Jayawardena S. Common cold symptoms in children: results of an Internet-based surveillance program. J Med Internet Res 2014; 16(6): e144.

53. Hryniewicz W, Albrecht P, Radzikowski A, eds. Rekomendacje postępowania w pozaszpitalnych zakażeniach układu oddechowego 2016. Warszawa: Narodowy Instytut Leków; 2016. Available from URL: http://antybiotyki.edu.pl/wp-content/uploads/Rekomendacje/Rekomendacje2016.pdf (in Polish).

54. Eccles R. Understanding the symptoms of the common cold and influenza. Lancet Infect Dis 2005; 5(11): 718-725.

55. Samoliński B, Krzych-Fałta E, Wojas O, et al. COVID-19 - recommendations for allergists and ENT specialists. Alergoprofil 2020; 1(16): 3-7, doi: 10.24292/01.AP.161311320 (in Polish).

56. Thompson M, Vodicka TA, Blair PS, et al. Duration of symptoms of respiratory tract infections in children: systematic review. BMJ 2013; 347: f7027.

57. Aabenhus R, Jensen JUS, Jørgensen KJ. Biomarkers as point-of-care tests to guide prescription of antibiotics in patients with acute respiratory infections in primary care. Cochrane Database Syst Rev 2014; 11: CD010130, doi: 10.1002/14651858.CD010130.pub2.

58. Tonkin-Crine SK, Tan PS, Hecke $O$ van, et al. Clinician-targeted interventions to influence antibiotic prescribing behaviour for acute respiratory infections in primary care: an overview of systematic reviews. Cochrane Database Syst Rev 2017; 9(9): CD012252, doi: 10.1002/14651858.CD012252.pub2.

59. Srugo I, Klein A, Stein M, et al. Validation of a novel assay to distinguish bacterial and viral infections. Pediatrics 2017; 140(4): e20163453, doi: 10.1542/peds.2016-3453.

60. Murdoch DR, Werno AM, Jennings LC. Microbiological diagnosis of respiratory illness: recent advances. Kendig's Disorders of the Respiratory Tract in Children 2019: 396-405, doi: 10.1016/B978-0-323-44887-1.00022-5.

61. Jaguś P, Chorostowska-Wynimko J, Roży A. Diagnostyka wybranych zakażeń wirusowych układu oddechowego. Pneumonol Alergol Pol 2010; 78, 1: 47-53.

62. Hansen G, Marino J, Wang ZX, et al. Clinical performance of the point-of-care cobas Liat for detection of SARS-CoV-2 in 20 minutes: a multicenter study. J Clin Microbiol 2020; 25: JCM.02811-20, doi: 10.1128/JCM.02811-20.

63. Coronavirus Disease 2019 (COVID-19) Emergency use authorizations for medical devices. In vitro diagnostics EUAs [cited 1.02.2021]. Available from URL: https://www.fda.gov/medical-devices/coronavirus-disease-2019-covid-19-emergency-use-authorizations-medical-devices/vitro-diagnostics-euas\#individual-antigen.

64. Scohy A, Anantharajah A, Bodéus M, et al. Low performance of rapid antigen detection test as frontline testing for COVID-19 diagnosis. J Clin Virol 2020; 129: 104455, doi: 10.1016/j.jcv.2020.104455.

65. Lambert-Niclot S, Cuffel A, Le Pape S, et al. Evaluation of a rapid diagnostic assay for detection of SARS-CoV-2 antigen in nasopharyngeal swabs. J Clin Microbiol 2020; 58(8): e00977-e00920, doi: 10.1128/JCM.00977-20.

Tables: 4

Figures: 1

References: 65

Received: 02.02.2021

Reviewed: 13.03.2021

Accepted: 05.10.2021

Address for correspondence:

Ewelina Wawryk-Gawda, MD, PhD

Klinika Chorób Płuc i Reumatologii Dziecięcej

Uniwersytet Medyczny w Lublinie

ul. Prof. Antoniego Gębali 6

20-093 Lublin

Polska

Tel.: +48 81 718-54-53, 508 191-144

E-mail: ewelina.wawryk@wp.pl 